\title{
Heat Shock Protein 70 Expression in Giant Cell Tumor of Bone and Its Clinical Application
}

\author{
Apichat Asavamongkokul', Pojchong Chotiyarnwonga', Nednapis Tirawanchai2, \\ Saranatra Waikakul ${ }^{*}$ \\ ${ }^{1}$ Department of Orthopaedic Surgery, Faculty of Medicine Siriraj Hospital, Mahidol University, Bangkok, \\ Thailand \\ ${ }^{2}$ Department of Biochemistry, Faculty of Medicine Siriraj Hospital, Mahidol University, Bangkok, Thailand \\ Email: saranatra.wai@mahidol.ac.th
}

Received 2 January 2015; accepted 4 February 2015; published 9 February 2015

Copyright (C) 2015 by authors and Scientific Research Publishing Inc.

This work is licensed under the Creative Commons Attribution International License (CC BY). http://creativecommons.org/licenses/by/4.0/

(c) (i) Open Access

\section{Abstract}

Objective: To provide a better prognosis after the treatment of giant cell tumor of bone which is a common benign aggressive bone tumor by the use of thermoablation, Hsp70 expression of the tumor was explored and the relationship between the relative amount of expression of this protein and tumor recurrence was studied. Methods: Avascular parts of tumor tissues were collected from 11 patients, 3 male and 8 female with an average age of 32.27 years and were sent for the analysis of protein contents by the use of Western blot. A comparative protein analysis was used for the detection of Hsp70 and beta-actin. Monoclonal antibody was used for the identification of Hsp70. The measurement was carried out two times in one patient. The relationship between ratios of Hsp70/beta-actin and tumor recurrence during 3-year follow-up was carried out. Results: Tumor recurrence was found in 4 patients, $36.6 \%$ and none had lung metastasis. Significant HSP expression was found in all specimens. No patient with the ratio of HSP70/beta-actin expression lower than 0.66 had tumor recurrence. Sensitivity of the test was $75 \%$ and specificity was $100 \%$. Conclusion: Expression of Hsp70 was found in giant cell tumor of bone and high relative expression of this protein related to tumor recurrence.

\section{Keywords}

Giant Cell Tumor, Heat Shock Proteins, Tumor Recurrence, Bone Tumor, Thermoablation

\footnotetext{
${ }^{*}$ Corresponding author.
}

How to cite this paper: Asavamongkokul, A., Chotiyarnwonga, P., Tirawanchai, N. and Waikakul, S. (2015) Heat Shock Protein 70 Expression in Giant Cell Tumor of Bone and Its Clinical Application. Surgical Science, 6, 26-34. 


\section{Introduction}

Under stressful conditions most cells produce heat shock proteins (Hsps) which can provide both a protective mechanism for the affected cells and a stimulation of immune response [1]. Hsp70 Kilo-Dalton acts as a chaperone for folding up all polypeptide molecules for their proper forms and functions. This protein can stabilize most proteins in the cells and they also play major role in the prevention of apoptosis of the cells [2]. Recently, there have been many reports of the expression of HSPs in particular tumors, especially malignant tumors such as leukemia and osteosarcoma [3] [4]. Hsps can promote tumorigenesis and the prevention of tumor cell apoptosis [5]-[8]. The amount of Hsp expression in these malignant tumors seemed to correlate with the aggressiveness of the tumors [9] [10]. However, there was no report of Hsp expression in giant cell tumor of bone from our literature reviews.

Giant cell tumor of bone is one of the common benign aggressive bone tumors [11]-[15]. The aggressiveness and recurrence of giant cell tumor cannot be predicted from clinical and histopathological findings [16]. Recurrencerates between $6 \%$ and $16 \%$ after wide resection and $18 \%$ and $56 \%$ after extended intra-lesional curettage and local treatment have been reported [17]-[20]. Only early local recurrence rate was found to relate with the aggressiveness of this tumor [21]. To provide a better prediction of the recurrent rate at pre-operative stage, Hsp70 expression has been explored through tumor tissues. The study of the relationship between the relative amount of Hsp70 expression and clinical outcome of the treatment in terms of tumor recurrence was also carried out.

\section{Materials \& Methods}

The study was approved by Siriraj IRB number 771/2554. Tumor tissues were collected from 11 patients, 3 male and 8 female who had been treated at the Department of Orthopaedic Surgery, Faculty of Medicine Siriraj Hospital, Mahidol University, Bangkok, Thailand during 2011 to 2012, Table 1. Their ages ranged between 22 and 45 years with an average age of 31.3 years. All patients had the definitive diagnosis of giant cell tumor of bone with large soft tissue tumor mass as at least 10 cubic centimeters of the tumor tissues were needed for our test, Figure 1. Seven patients were recurrent cases and the rest 4 patients were new cases of giant cell tumor of bone. All patients were treated by the use of extended intralesional curettage and the tumor lesions were filled up with bone graft or bone cement.

Table 1. Biographic data of the patients and characteristics of the tumor.

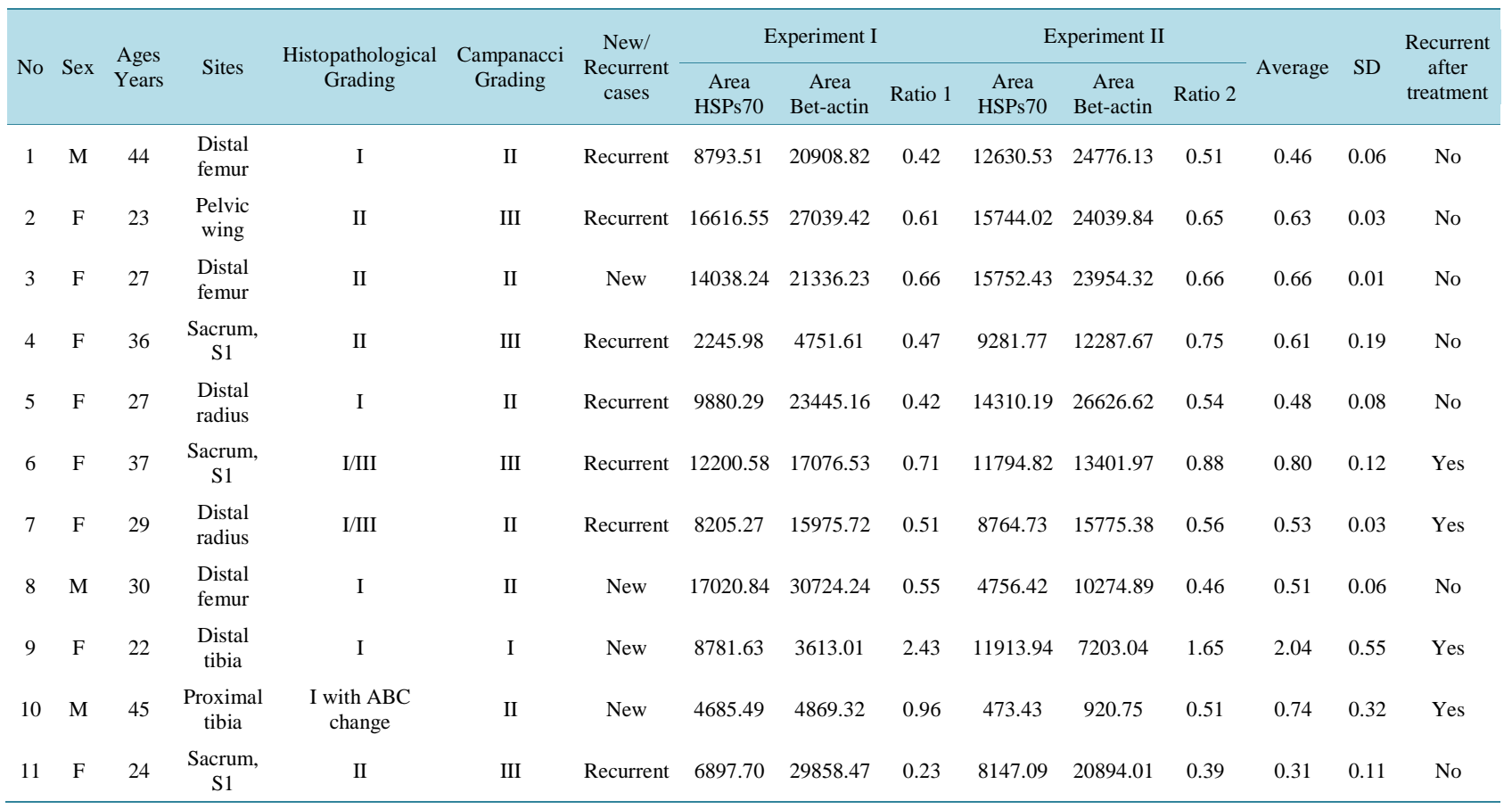




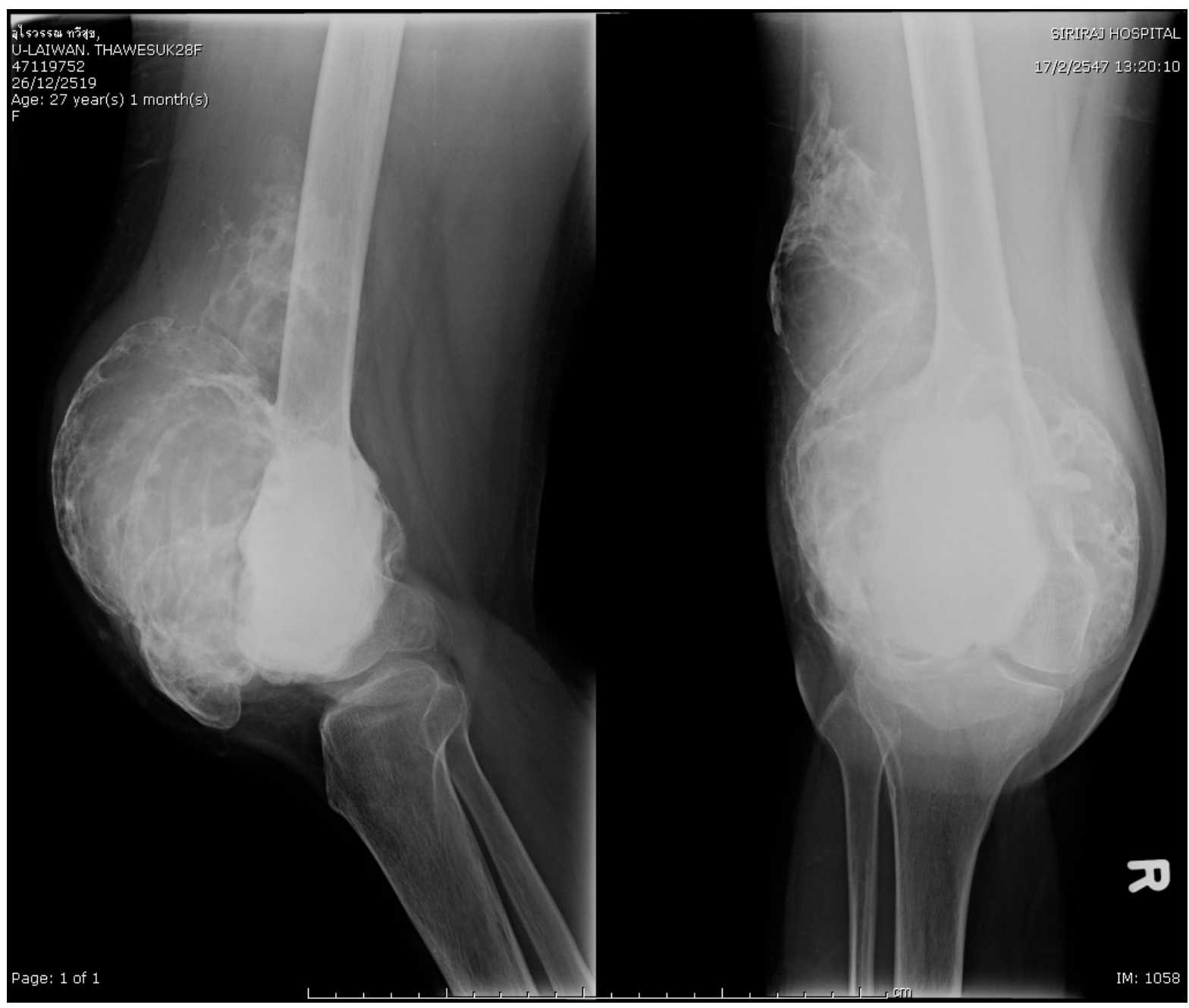

Figure 1. Radiograph of the patient number 1 who had recurrent giant cell tumor at his distal femur.

Ten cubic centimeters of avascular part of the tumor tissues were collected under sterile technique. The tissues were cut into small pieces by the use of a surgical knife. The tumor tissues were cleaned by the use of continuous irrigation with sterile normal saline to grossly remove all contaminating blood. Then, the tumor tissues were placed in sterile bottle at room temperature without any medium and were brought to storage immediately at $-20^{\circ} \mathrm{C}$ freezer in our laboratory.

For protein isolation, small pieces of tumor tissue of about $0.02 \mathrm{~g}$ were selected and were washed with $100 \mu \mathrm{l}$ of PBS. The supernatant was discarded. The tissues were homogenized after adding $200 \mu \mathrm{l}$ of PBS to the tube by the use of a mini-homogenizer and plastic pestle on ice. Ten to 15 strokes ( 3 - 4 seconds/stroke) during the homogenization were carried out. Then, the samples were spun at $12,000 \mathrm{~g}$ for 15 minutes at $4^{\circ} \mathrm{C}$ and the supernatant was discarded. Tissue pellets were re-suspended in $1 \times$ sample buffer in the same volume as the supernatant. The solution was transferred to a $0.6 \mathrm{~mL}$ microcentrifuge tube and sonicated briefly for $10-15$ seconds. Then, the solution was boiled for 5 minutes at $95^{\circ} \mathrm{C}$. After that, the sample was spun again at $12,000 \mathrm{~g}$ for another 10 minutes at $4^{\circ} \mathrm{C}$. The supernatants were collected for the determination of protein concentration by Bradford assay.

Western blot analysis was carried out in the study for detection of the target proteins. The process of the identification of Hsp70 was carried out by the use of a comparative proteinanalysis [22]. Identification of Hsp70 expression was carried out in this study because these proteins related to natural history of most tumor and might be the target of therapy in the future [23] [24].

Forty micrograms of each protein sample were mixed with $6 x$ sample buffer $(0.5 \mathrm{M}$ Tris- $\mathrm{HCl}, \mathrm{pH} 6.8$, plus 
0.4\% SDS, 30\% glycerol, 10\% SDS, 0.6 M DTT, 0.012\% bromphenol blue). The samples were loaded and run in SDS-polyacrylamide gel electrophoresis on a 10\% Tris-glycine polyacrylamide gel in 1xrunning buffer at 100 V for 1.5 hours ( $1 \times$ Tris/glycine/SDS buffer, Bio-Rad Laboratories, Hercules, CA, USA). After electrophoresis, the proteins were transferred to a nitrocellulose membrane (Bio-Rad) and left overnight in $1 \times$ transfer buffer (1× Tris/glycine buffer (Bio-Rad) plus $20 \%$ methanol) at $18 \mathrm{~V}$ under the temperature of $4^{\circ} \mathrm{C}$. The membranes were blocked for 30 minutes at room temperature in $5 \%$ skim milk and were washed out with $0.1 \%$ TBST $(1 \times$ TBS [Tris-buffered saline], BioRad, 0.1\% Tween $\left.{ }^{\circledR} 20\right)$. Then, membranes were incubated with Hsp70 Antibody, Mouse Monoclonal (Abcam., England) primary antibody (diluted 1:1000 in 5\% skim milk) at $4{ }^{\circ} \mathrm{C}$ with agitation. After one night of incubation, three procedures of 15 -minute washes in $0.1 \%$ TBST were carried out. AntiMouse IgG, HRP-linked Antibody (Abcam., England) was then added and the membranes were incubated for another 1 hour at room temperature with agitation (dilution 1:1000 in 5\% skim milk) and followed by three 15 minute washings in $0.1 \%$ TBST. The membranes were then soaked in ECL ${ }^{\text {TM}}$ Detection Reagent (Pierce, USA) for 5 minutes. Image was captured by Genesyn Program to get the results of Hsp70 expression. Band density was quantitated by the use of ImageJ (image analysis software program).

For beta-actin expression, after captured, the membranes were continuously washed for 30 minutes, 3 times, in $0.1 \%$ TBST. Then, the membranes were incubated with monoclonal anti-beta-actin produced in mouse (SigmaAldrich) with the dilution of 1:2000 in $5 \%$ skim milk for one night at $4^{\circ} \mathrm{C}$ with agitation. The membranes were undergone three times of 15-minute washing in 0.1\% TBST. Anti-Mouse IgG, HRP-linked Antibody (Abcam., England) was then added and the membranes were incubated for another 1 hour at room temperature with agitation (diluted 1:1000 in 5\% skim milk). Then, three times of 15-minute washing in 0.1\% TBST were carried out. The membranes were soaked in ECL ${ }^{\mathrm{TM}}$ Detection Reagent (Pierce, USA) for 5 minutes.

The relative amount of Hsp70 protein expression was calculated by band density of Hsp70 divided by band density of beta-actin. The expression of protein band was measured by the use of a densitometer. The measurement was carried out two times (duplicated studies) in each patient, Figure 2.

The data were analyzed by the use of SPSS Window version 16 statistical package. All patients were followed up for at least 3 years. Recurrence rate and the progression of the tumor were closely followed up by the use of physical examination and plain radiography every month during the $1^{\text {st }}$ year and every 3 months during the $2^{\text {nd }}$ and $3^{\text {rd }}$ year follow up. MRI was used for the confirmation of tumor recurrence and surgical planning. Relationship between the relative amount of Hsp70 protein expression and tumor recurrence was observed and formulated as a diagnostic test.

\section{Results}

All patients survived the surgery and were closely followed up between 40 - 50 months with the average being 42.4 months. Hsp70 expression was found in the specimens of all patients, Table 1. Four patients, 36.6\%, 1 male and 3 female, developed tumor recurrence, patient numbers 6, 7, 9 and 10. None had lung metastasis. Two had histopathological grade I/III and 1 patient had giant cell tumor grade I with aneurysmal bone cyst component. Three patients in the tumor recurrence group had high ratio between area of Hsp70 and beta-actin (Hsp70/beta-actin), ranging between 0.74 and 2.04. One patient with recurrent tumor, patient number 7, had low Hsp70/beta-actin ratio, 0.53. All patients who had no tumor recurrence had ratios between 0.31 and 0.66, Table 1.

As the experiment was carried out two times, the intra class coefficient (ICC) was calculated and the result was 0.789 , Table 2 . By the use of $F$ test the $\mathrm{p}$-value was 0.001 . These findings supported the fact that results from the 2 experiments correlated with each other significantly and indicated similarity of the results. From group statistics, the patients who had high ratio of Hsp70/beta-actin trended to have a higher chance to develop tumor recurrence, even though there was no significant difference.

YOUDEN Index was used to find out the cutoff point of Hsp70/beta-actin ratio to differentiate between the tumor recurrence and the non-tumor recurrence groups. At YOUDEN Index of 0.75, the cutoff point was 0.66, Table 3. This cutoff point was confirmed by the use of ROC curve, Figure 3 and dot diagram, Figure 4 . The area under the curve (AUC) was 0.893 with the standard error (SE) of 0.112 . The lower bound was 0.674 and the upper bound was 1.111 at $95 \%$ confidence interval. The pre-test prevalence was $36.3 \%$. Post-test probability or recurrence rates ranged between $12 \%$ and $36.3 \%$ when the test gave negative results, Table 3. Post-test probability or recurrence rates would be higher than $74.7 \%$ when the test gave positive results, Table 3 . 


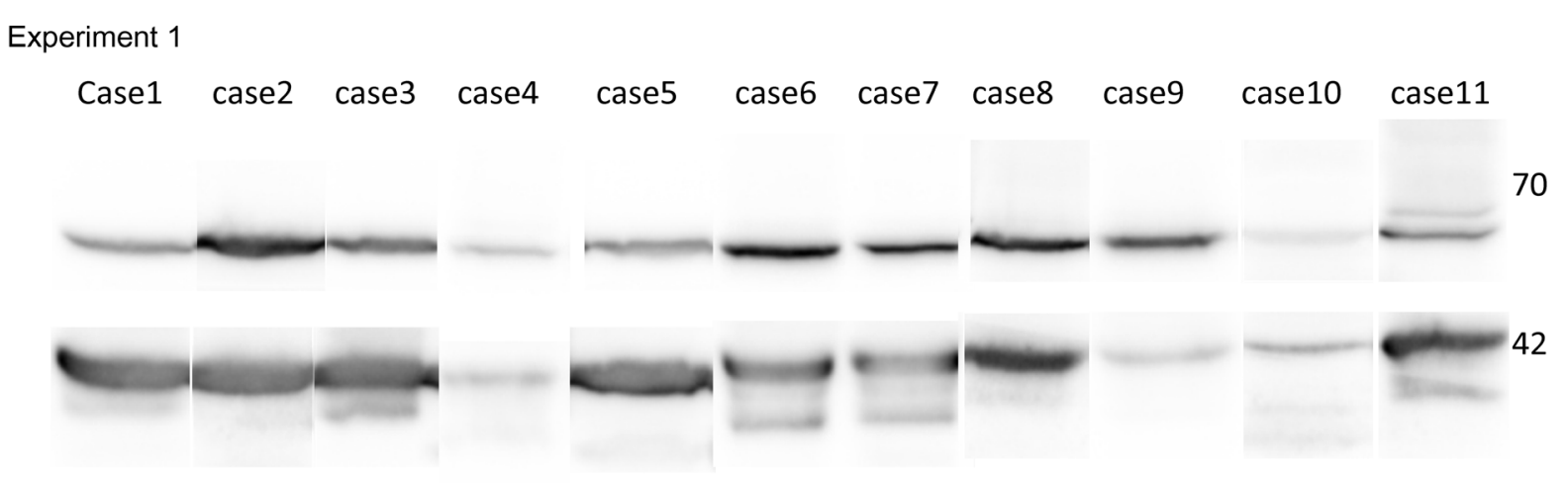

\section{Experiment2}

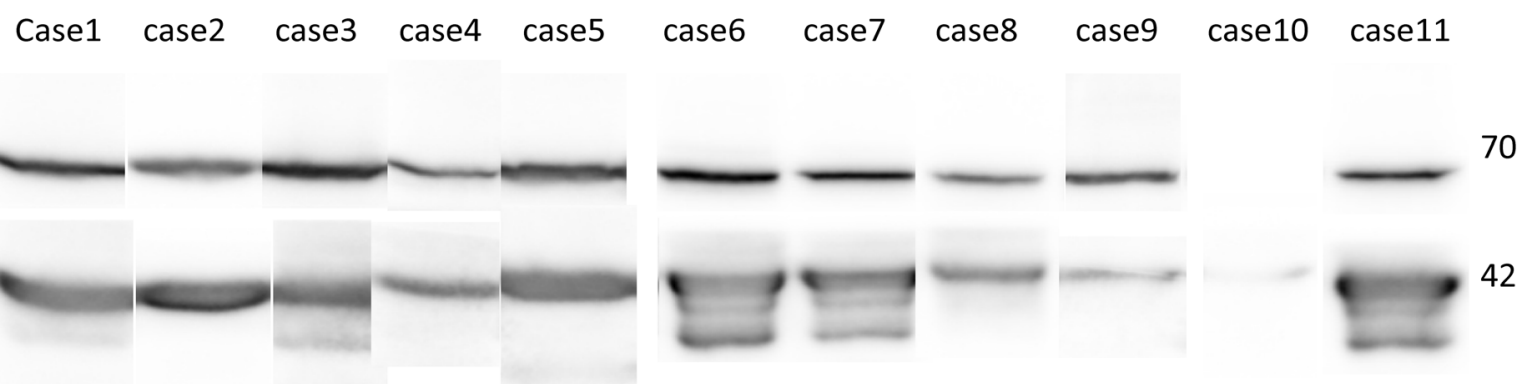

Figure 2. Western blot analysis showed expression of Hsp70 (70 kDa) comparing with beta-actin protein (42 kDa).

Table 2. Intraclass correlation coefficient, two-way random effects model where both people effects and measures effects are random.

\begin{tabular}{|c|c|c|c|c|c|}
\hline & \multirow{2}{*}{ Intraclass coefficient $^{1}$} & \multicolumn{2}{|c|}{ 95\% Confidence interval } & \multicolumn{2}{|c|}{ F test with true value } \\
\hline & & Lower bound & Upper bound & Value & $P$ value \\
\hline Single measures & 0.798 & 0.410 & 0.941 & 8.891 & 0.001 \\
\hline Average measures & 0.888 & 0.582 & 0.970 & 8.891 & 0.001 \\
\hline
\end{tabular}

${ }^{1}$ Type C intraclass correlation coefficients using a consistency definition-the between-measure variance is excluded from the denominator variance.

Table 3. Cutoff point ratio was 0.66 by the use of YOUDEN INDEX $=0.75$.

\begin{tabular}{|c|c|c|c|c|c|c|c|}
\hline Criterion & $\begin{array}{l}\text { Sensitivity } \\
\text { (95\% C.I.) }\end{array}$ & $\begin{array}{l}\text { Specificity } \\
\text { (95\% C.I.) }\end{array}$ & $\begin{array}{c}\text { Positive } \\
\text { likelihood ratio }\end{array}$ & $\begin{array}{c}\text { Negative } \\
\text { likelihood ratio }\end{array}$ & $\begin{array}{c}\text { Positive } \\
\text { predictive value }\end{array}$ & $\begin{array}{c}\text { Negative } \\
\text { predictive value }\end{array}$ & $\begin{array}{c}\text { YOUDEN } \\
\text { INDEX }\end{array}$ \\
\hline 0.31 & $100.0(40.2-100.0)$ & $0.0(0.0-41.1)$ & 1.00 & & 0.4 & & \multirow{12}{*}{$\underline{0.75}$} \\
\hline 0.31 & $100.0(40.2-100.0)$ & $14.3(2.4-57.8)$ & 1.17 & 0.00 & 0.4 & 100.0 & \\
\hline 0.46 & $100.0(40.2-100.0)$ & $28.6(4.5-70.7)$ & 1.40 & 0.00 & 0.5 & 100.0 & \\
\hline 0.48 & $100.0(40.2-100.0)$ & $42.9(10.4-81.2)$ & 1.75 & 0.00 & 0.6 & 100.0 & \\
\hline 0.51 & $100.0(40.2-100.0)$ & $57.1(18.8$ - 89.6) & 2.33 & 0.00 & 0.8 & 100.0 & \\
\hline 0.53 & $75.0(20.3$ - 95.9) & $57.1(18.8$ - 89.6) & 1.75 & 0.44 & 0.6 & 99.8 & \\
\hline 0.61 & $75.0(20.3$ - 95.9) & $71.4(29.3$ - 95.5) & 2.62 & 0.35 & 0.9 & 9.99 & \\
\hline 0.63 & $75.0(20.3$ - 95.9) & $85.7(42.2$ - 97.6) & 5.25 & 0.29 & 1.9 & 99.9 & \\
\hline$\underline{0.66}$ & $\underline{75.0(20.3-95.9)}$ & $100.0(58.9-100.0)$ & & $\underline{0.25}$ & $\underline{100.0}$ & $\underline{99.9}$ & \\
\hline 0.74 & $50.0(8.3-91.7)$ & $100.0(58.9-100.0)$ & & 0.50 & 100.0 & 99.8 & \\
\hline 0.8 & $25.0(4.1-79.7)$ & $100.0(58.9-100.0)$ & & 0.75 & 100.0 & 99.7 & \\
\hline 2.04 & $0.0(0.0-59.8)$ & $100.0(58.9-100.0)$ & & 1.00 & & 99.6 & \\
\hline
\end{tabular}

Variable $=$ ratio of HSP 70/beta-actin, classification variable $=$ recurrent, positive group recurrent $=3 / 4$, negative group recurrent $=0 / 7$, disease prevalence $=36.3 \%$, area under the ROC curve $=0.893$, SE $=0.119,95 \%$ confidence interval $=0.567-0.985$. 


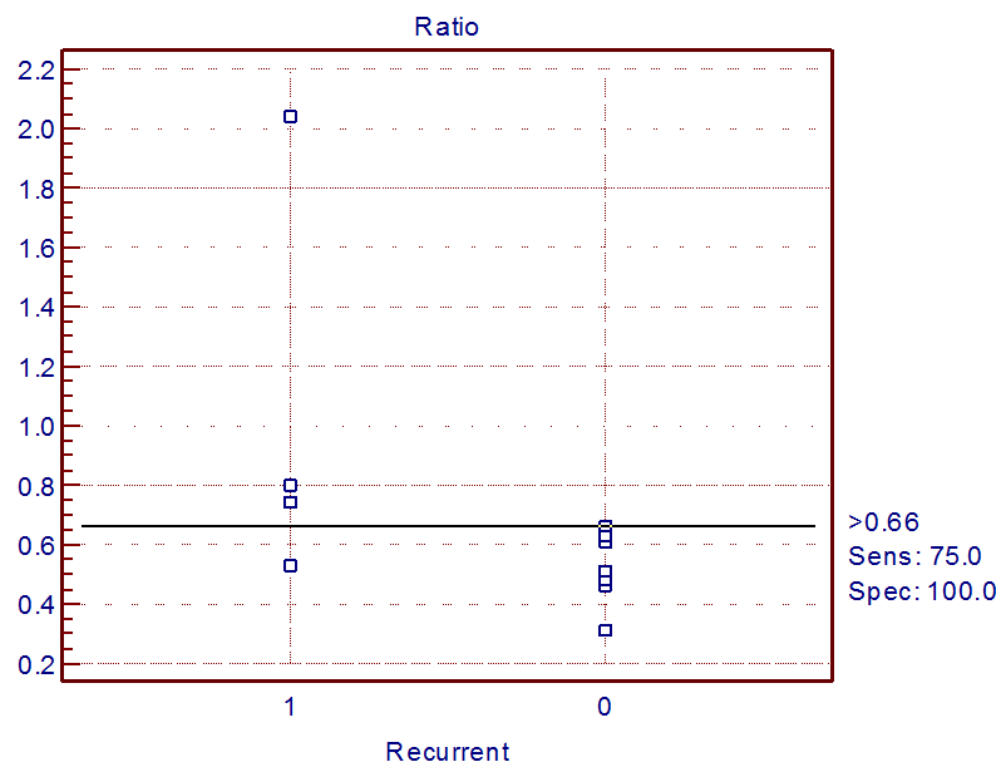

Figure 3. Dot-diagram of the ratio between Hsp70 and beta-actin.

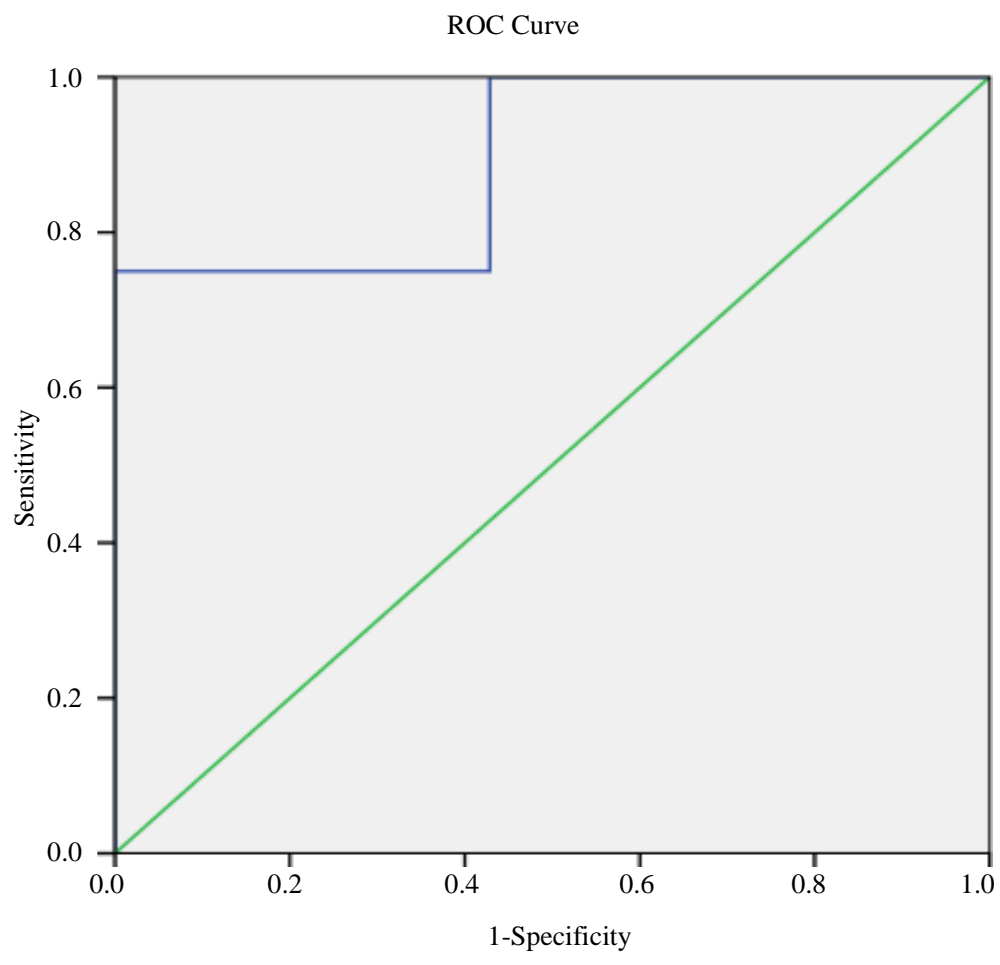

Figure 4. ROC curve of the ratio between Hsp70 and beta-actin.

\section{Discussion}

All patients had the definitive diagnosis of giant cell tumor of bone made by our Tumor Board which consisted of bone pathologists, musculoskeletal radiologists, orthopaedic surgeons and medical oncologists. From a previous report of the Eastern Asian Musculoskeletal Oncology Group, the median interval between initial surgery and the first recurrence of the new cases was 16 months. The mean interval between the surgeries in the recurrent cases was 14.1 months for the repeated recurrent groups and 28.3 months for the single recurrent group [21]. Thus, all patients in this study were followed up for at least 36 months, ranging between 40 and 50 months with 
an average follow up of 42.4 months. Tumor recurrence during the follow up was used as the gold standard measurement of this diagnostic test.

Our patients' biographic data, location of the tumor and tumor pathology can represent the patients of our clinical practices which were similar to most reports [11]-[15] [25]. Concerning tumor location and pathology, most of the enrolled patients had the tumor at the end of their long bones and they were pathological type II. These results were also similar to the patients in most reports too. However, 2 of our patients, patient numbers 6 and 11, had the tumor at their sacrums, which was rather rare.

The tumor tissues of all patients had Hsp70 expression which has not been reported in any previous literatures. Interestingly, Hsp70 was one of the proteins which can potentiate aggressiveness of particular tumors [3] [4] [26]. The positive relationship between the ratios of HSP70/beta-actin expression and tumor recurrent rates of giant cell tumor of bone was demonstrated in this study. Different tumor might have different Hspexpression. The data from this study should not be applied for other bone tumors. The limitation of this study was its small sample size as only 11 patients were included in the study.

High ratio of Hsp70/beta-actin related to the tumor recurrence. Therefore, the possibility of using the ratio as a preoperative predictor of tumor recurrence was carried out. With the cutoff point of the ratio of 0.66 , acceptable sensitivity of $75 \%$ and high specificity of $100 \%$, were the results. Furthermore, encouraging results in terms of both positive and negative predictive values and positive and negative likelihood ratio were also observed.

Minimizing tumor recurrence rate was our goal because the higher the recurrence rate of the tumor, the poorer outcome of the treatment has been reported [21]. By the use of this test, the post-test probability was significantly enhanced, Table 3. The information could be used for decision making in the selection of the type of surgery and the local treatment method to minimize tumor recurrence rate. When the Hsp70/beta-actin ratio was lower than 0.66 , post-test probability or recurrence rate would be lowered and ranged between $12 \%$ and $36.3 \%$. Less invasive or ablative surgery might be considered in the patient to preserve function. On the other hand, when the Hsp70/beta-actin ratio was higher than 0.66 , post-test probability or recurrence rate would be higher than $74.7 \%$. More extensive surgery should thus be considered in the patient to minimize recurrence rate. However, longer terms of follow up and the recruiting of more patients and specimens should be carried out before the test can be used confidently as a standard diagnostic test. Concerning the expenses of the test, the relative expression of Hsp70/beta-actin should be limited to be used in patients who have repeated tumor recurrence and patients who had large tumor masses which might need aggressive ablative surgery and enough tumor samples to be collected for the test.

\section{Conclusion}

In conclusion, Hsp70 expression was found at a certain level in the specimens from all patients who had giant cell tumor of the bone. The ratio between Hsp70 and beta-actin should be a possible predictor of tumor recurrence.

\section{Acknowledgements}

This study was totally supported by Prasert Prasarttong-OsothResearch Foundation which is operated by the Medical Association of Thailand.

\section{Disclosure}

The authors have no conflict of interest.

\section{References}

[1] Tamura, Y., Torigoe, T., Kukita, K., Saito, K., Okuya, K., Kutomi, G., Hirata, K. and Sato, N. (2012) Heat-Shock Proteins as Endogenous Ligands Building a Bridge between Innate and Adaptive Immunity. Immunotherapy, 4, 841-852. http://dx.doi.org/10.2217/imt.12.75

[2] Taldone, T., Patel, H.J., Bolaender, A., Patel, M.R. and Chiosis, G. (2014) Protein Chaperones: A Composition of Matter Review (2008-2013). Expert Opinion on Therapeutic Patents, 24, 501-518. http://dx.doi.org/10.1517/13543776.2014.887681

[3] Moon, A., Bacchini, P., Bertoni, F., Olvi, L.G., Santini-Araujo, E., Kim, Y.W. and Park, Y.K. (2010) Expression of Heat Shock Proteins in Osteosarcomas. Pathology, 42, 421-425. http://dx.doi.org/10.3109/00313025.2010.493866 
[4] Sedlackova, L., Spacek, M., Holler, E., Imryskova, Z. and Hromadnikova, I. (2011) Heat-Shock Protein Expression in Leukemia. Tumor Biology, 32, 33-44. http://dx.doi.org/10.1007/s13277-010-0088-7

[5] Guzhova, I.V., Shevtsov, M.A., Abkin, S.V., Pankratova, K.M. and Margulis, B.A. (2013) Intracellular and Extracellular Hsp70 Chaperone as a Target for Cancer Therapy. International Journal of Hyperthermia, 29, 399-408. http://dx.doi.org/10.3109/02656736.2013.807439

[6] Juhasz, K., Lipp, A.M., Nimmervoll, B., Sonnleitner, A., Hesse, J., Haselgruebler, T. and Balogi, Z. (2013) The Complex Function of hsp70 in Metastatic Cancer. Cancers, 6, 42-66. http://dx.doi.org/10.3390/cancers6010042

[7] Dodd, K., Nance, S., Quezada, M., Janke, L., Morrison, J.B., Williams, R.T. and Beere, H.M. (2014) Tumor-Derived Inducible Heat-Shock Protein 70 (HSP70) Is an Essential Component of Anti-Tumor Immunity. Oncogene.

[8] Sun, C., Li, H.L., Shi, M.L., Liu, Q.H., Bai, J. and Zheng, J.N. (2014) Diverse Roles of C-Terminal Hsp70-Interacting Protein (CHIP) in Tumorigenesis. Journal of Cancer Research and Clinical Oncology, 140, 189-197. http://dx.doi.org/10.1007/s00432-013-1571-5

[9] Uozaki, H., Ishida, T., Kakiuchi, C., Horiuchi, H., Gotoh, T., Iijima, T., Imamura, T. and Machinami, R. (2000) Expression of Heat Shock Proteins in Osteosarcoma and Its Relationship to Prognosis. Pathology—Research and Practice, 196, 665-673. http://dx.doi.org/10.1016/S0344-0338(00)80118-1

[10] Murphy, M.E. (2013) The HSP70 Family and Cancer. Carcinogenesis, 34, 1181-1188. http://dx.doi.org/10.1093/carcin/bgt111

[11] Larsson, S.E., Lorentzon, R. and Boquist, L. (1975) Giant-Cell Tumor of Bone. A Demographic, Clinical, and Histopathological Study of All Cases Recorded in the Swedish Cancer Registry for the Years 1958 through 1968. Journal of Bone and Joint Surgery. American Volume, 57, 167-173.

[12] Arthornthurasook, A. (1979) Giant Cell Tumor of Bones: 5 Years of Study. Journal of the Medical Association of Thailand, 62, 260-263.

[13] Sung, H.W., Kuo, D.P., Shu, W.P., Chai, Y.B., Liu, C.C. and Li, S.M. (1982) Giant-Cell Tumor of Bone: Analysis of Two Hundred and Eight Cases in Chinese Patients. Journal of Bone and Joint Surgery. American Volume, 64, 755-761.

[14] Pongkripetch, M. and Sirikulchayanonta, V. (1989) Analysis of Bone Tumors in Ramathibodi Hospital, Thailand during 1977-1986: Study of 652 Cases. Journal of the Medical Association of Thailand, 72, 621-628.

[15] Settakorn, J., Lekawanvijit, S., Arpornchayanon, O., Rangdaeng, S., Vanitanakom, P., Kongkarnka, S., Cheepsattayakorn, R., Ya-In, C. and Thorner, P.S. (2006) Spectrum of Bone Tumors in Chiang Mai University Hospital, Thailand According to WHO Classification 2002: A Study of 1,001 Cases. Journal of the Medical Association of Thailand, 89, 780-787.

[16] Chanchairujira, K., Jiranantanakorn, T., Phimolsarnti, R., Asavamongkolkul, A. and Waikakul, S. (2011) Factors of Local Recurrence of Giant Cell Tumor of Long Bone after Treatment: Plain Radiographs, Pathology and Surgical Procedures. Journal of the Medical Association of Thailand, 94, 1230-1237.

[17] Turcotte, R.E., Wunder, J.S., Isler, M.H., Bell, R.S., Schachar, N., Masri, B.A., Moreau, G. and Davis, A.M., Canadian Sarcoma Group (2002) Giant Cell Tumor of Long Bone: A Canadian Sarcoma Group Study. Clinical Orthopaedics and Related Research, 397, 248-258. http://dx.doi.org/10.1097/00003086-200204000-00029

[18] Klenke, F.M., Wenger, D.E., Inwards, C.Y., Rose, P.S. and Sim, F.H. (2011) Recurrent Giant Cell Tumor of Long Bones: Analysis of Surgical Management. Clinical Orthopaedics and Related Research, 469, 1181-1187. http://dx.doi.org/10.1007/s11999-010-1560-9

[19] Niu, X.H., Zhang, Q., Hao, L., Ding, Y., Li, Y., Xu, H.R. and Liu, W.F. (2012) Giant Cell Tumor of the Extremity: Retrospective Analysis of 621 Chinese Patients from One Institution. The Journal of Bone and Joint Surgery (American), 94, 461-467. http://dx.doi.org/10.2106/JBJS.J.01922

[20] van der Heijden, L., Dijkstra, P.D., van de Sande, M.A., Kroep, J.R., Nout, R.A., van Rijswijk, C.S., Bovée, J.V., Hogendoorn, P.C. and Gelderblom, H. (2014) The Clinical Approach toward Giant Cell Tumor of Bone. The Oncologist, 19, 550-561. http://dx.doi.org/10.1634/theoncologist.2013-0432

[21] Takeuchi, A., Tsuchiya, H., Niu, X., Ueda, T., Jeon, D.G., Wang, E.H.M., Asavamongkolkul, A., Kusuzaki, K., Sakayama, K. and Kang, Y.K. (2011) The Prognostic Factors of Recurrent GCT: A Cooperative Study by the Eastern Asian Musculoskeletal Oncology Group. Journal of Orthopaedic Science, 16, 196-202. http://dx.doi.org/10.1007/s00776-011-0030-x

[22] Conti, A., Rodriguez, G.C., Chiechi, A., Blazquez, R.M., Barbado, V., Krènacs, T., Novello, C., Pazzaglia, L., Quattrini, I., Zanella, L., Picci, P., De Alava, E. and Benassi, M.S. (2011) Identification of Potential Biomarkers for Giant Cell Tumor of Bone Using Comparative Proteomics Analysis. American Journal of Pathology, 178, 88-97. http://dx.doi.org/10.1016/j.ajpath.2010.11.035

[23] Larocca, L.M., Ranelletti, F.O., Maggiano, N., Rutella, S., La Barbera, E.O., Rumi, C., Serra, F., Voso, M.T., Piantelli, M., Teofili, L. and Leone, G. (1997) Differential Sensitivity of Leukemic and Normal Hematopoietic Progenitors to the 
Killing Effect of Hyperthermia and Quercetin Used in Combination: Role of Heat-Shock Protein-70. International Journal of Cancer, 73, 75-83. http://dx.doi.org/10.1002/(SICI)1097-0215(19970926)73:1<75::AID-IJC13>3.0.CO;2-4

[24] Ueda, G., Tamura, Y., Hirai, I., Kamiguchi, K., Ichimiya, S., Torigoe, T., Hiratsuka, H., Sunakawa, H. and Sato, N. (2004) Tumor-Derived Heat Shock Protein 70-Pulsed Dendritic Cells Elicit Tumor-Specific Cytotoxic T Lymphocytes (CTLs) and Tumor Immunity. Cancer Science, 95, 248-253. http://dx.doi.org/10.1111/j.1349-7006.2004.tb02211.x

[25] Baena-Ocampo Ldel, C., Ramirez-Perez, E., Linares-Gonzalez, L.M. and Delgado-Chavez, R. (2009) Epidemiology of Bone Tumors in Mexico City: Retrospective Clinicopathologic Study of 566 Patients at a Referral Institution. Annals of Diagnostic Pathology, 13, 16-21. http://dx.doi.org/10.1016/j.anndiagpath.2008.07.005

[26] Tan, S.S., Ahmad, I., Bennett, H.L., Singh, L., Nixon, C., Seywright, M., Barnetson, R.J., Edwards, J. and Leung, H.Y. (2011) GRP78 Up-Regulation Is Associated with Androgen Receptor Status, Hsp70-Hsp90 Client Proteins and Castrate-Resistant Prostate Cancer. Journal of Pathology, 223, 81-87. http://dx.doi.org/10.1002/path.2795 
Scientific Research Publishing (SCIRP) is one of the largest Open Access journal publishers. It is currently publishing more than 200 open access, online, peer-reviewed journals covering a wide range of academic disciplines. SCIRP serves the worldwide academic communities and contributes to the progress and application of science with its publication.

Other selected journals from SCIRP are listed as below. Submit your manuscript to us via either submit@scirp.org or Online Submission Portal.
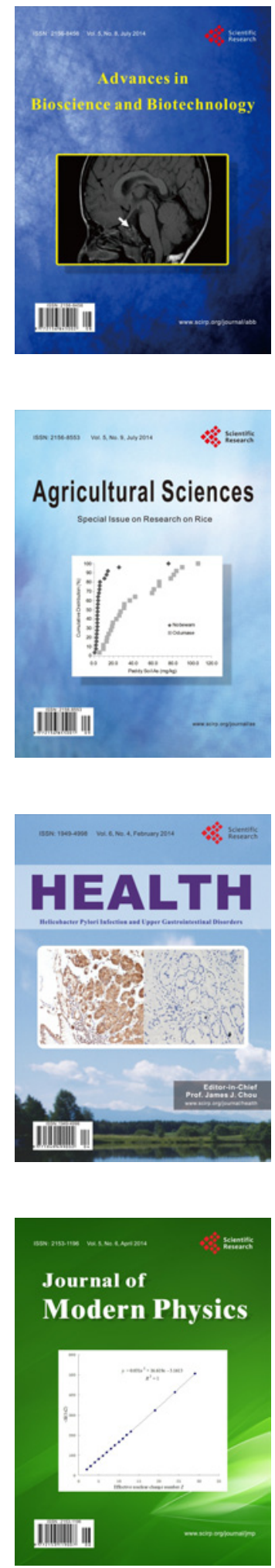
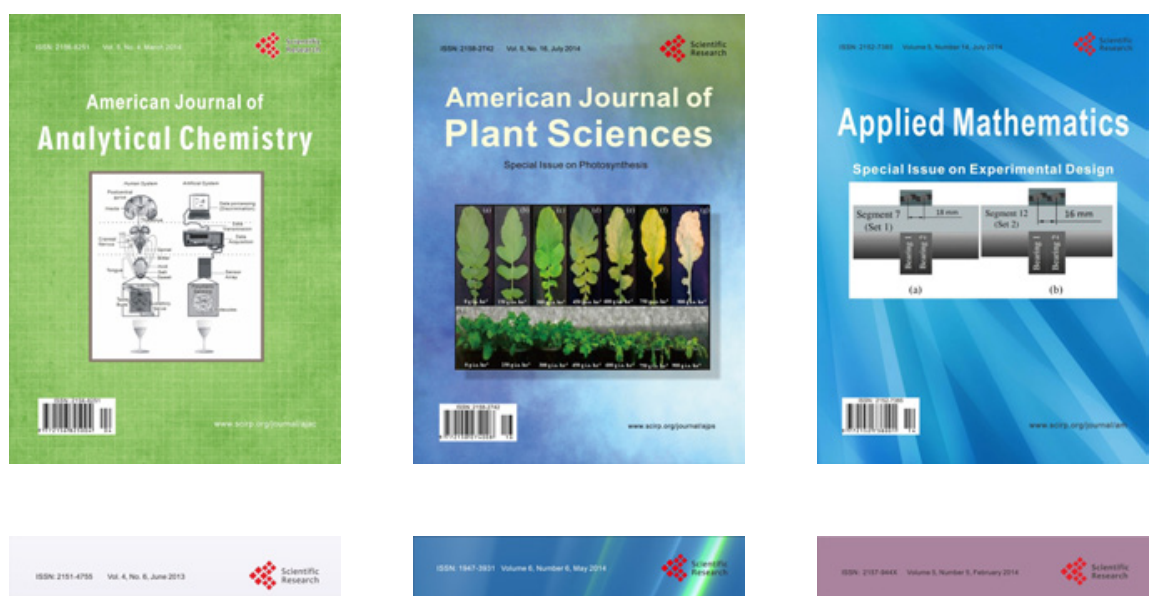

Creative Education
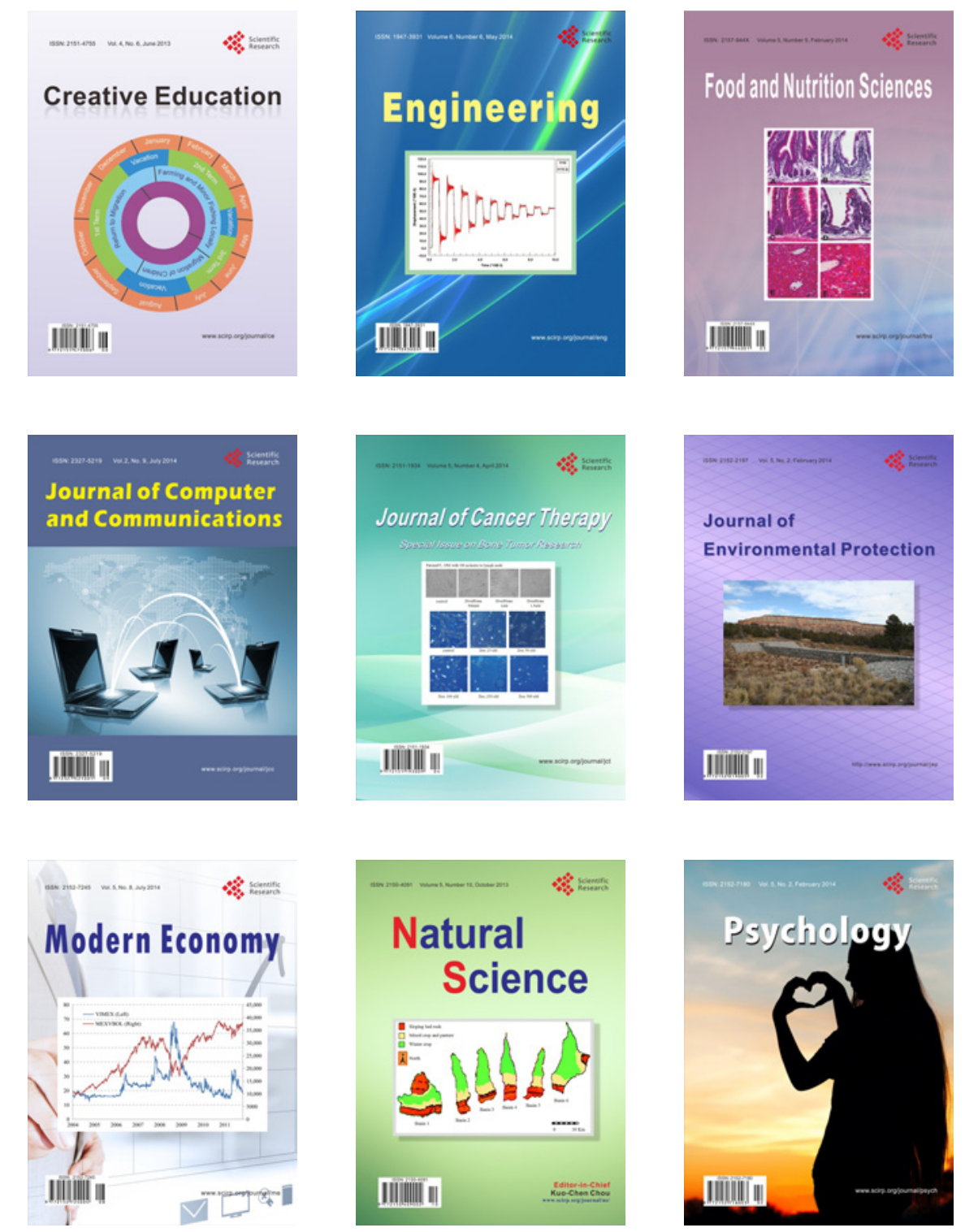